\title{
Cui bono? Good for whom? Some apologies, confessions, musings, unsubstantiated views, not empirically founded statements, lists, a few commandments, reading suggestions, and rather practical tips for aspiring and experienced bioethicists
}

\author{
Inez de Beaufort
}

Correspondence to Inez de Beaufort, Department of Medical Ethics and Philosophy of Medicine, Erasmus Medical Centre P.O. Box 2040, Rotterdam 3000 CA, The Netherlands; i.debeaufort@erasmusmc.nl

Received 1 September 2014 Revised 6 September 2014 Accepted 3 October 2014
CrossMark

To cite: de Beaufort I. J Med Ethics 2015;41:5659.

\section{ABSTRACT}

Probably almost every day (good working day) in 35 years of 'doing' medical ethics I have asked myself: for whom is good medical ethics good? Who benefits from our critical ethical analysis? In my view the ultimate justification of bioethics lies in contributing to the debate on problems people experience in real life and to changing practices. I discuss some pitfalls and problems present-day bioethicists encounter in an interdisciplinary climate, facing scepticism, competition and scarcity of resources, such as disdain from philosophers, take-over by other disciplines, dilution of ethical argument, the empirical seduction, and paragraph ethics.

Dedicated to Dr. Els Borst, former Minister of Health of the Netherlands, fighter for the patients' cause and the legalization of euthanasia, defender of ethics, critical of quick ethical fixes, wise and with a wonderful sense of humour, brutally murdered in February 2014

\section{TO DO GOOD MEDICAL ETHICS IS GOOD}

Ethicists' diseases? What is there but stress and professional envy?

Well, let me enlighten you: there is casuistritis, binge-philosophising, Harrisitis complex, Ross' syndrome, principlitis seriosa also called $\mathrm{B} \& \mathrm{C}$ disease, argumentorrhoea, intuitosis, empirical mood swings, post-traumatic IRB stress, stroke of moral luck, heuristiculitis, existential doubtism, Rawls' disease, and Millinoma. And the worst of it is, all are extremely contagious. Just a few patients and you have an epidemic on your hands.

No cures, I suppose? ${ }^{1}$

Of course it is good to do medical ethics. Of course there is good medical ethics. (And bad for that matter, as other contributions to this issue will doubtless indicate.) Doctors are grateful for the useful insights and the attention paid to their harrowing dilemmas. Medical students are fascinated by ethical dilemmas and the best want to become medical ethicists themselves. Those who still chose a medical career know that they will be truly better doctors for having considered medical ethics. Medical professors are delighted that finally they don't have to do the ethical teaching themselves, as they readily acknowledged that they lacked some knowledge. Researchers are grateful for being kept from doing Highly Unethical Things and for the appropriate slowing down of the progress of science which they could not have managed by themselves. Medical faculties open their arms and invest in blooming and booming ethics departments. Patients are delighted that someone passionately cares about their predicament. Governments, ministers of health and other political dignitaries gladly appoint ethicists to Important Committees of Wise Persons to advise them on all matters medical-ethical, committees which write thoughtful readable reports radiating rational consensus. Policymakers will immediately shape equally rational policies on these proposals so that the world becomes a better place. Sometimes politicians are particularly relieved as they can use the committees to stall or store complicated decisions or cover up their lack of decision making (or flawed decisions). Colleagues in the field of ethics are thrilled that their intricate theoretical insights designed in armchairs and Ivory Towers are applied to real life problems by the humble and toiling bioethicists who carry on with their profession in the mud of real life. Funding organisations are delighted to invest in this most highly validationprone research and these diligent researchers who organise interesting conferences and write wonderful books (well, in the good old days, now most publish in High Impact Journals). Television programmes thrive on academics who by expertly and eloquently shooting from the hip, stimulate the societal debate. The public adores the wisdom of the DPhils of philosophy on Prime Time Ethics.

Well, it is a human right to dream (or share nightmares). So why and for whom medical ethics?

\section{GOOD FOR PATIENTS? OUTRAGE. THE STORY OF M.}

A novice bioethicist should analyse her motivation. What do you want to accomplish and for whom? Meeting $\mathrm{M}$ during my studies motivated me. $\mathrm{M}$ was a 21-year-old foreign student who died of testis cancer in the Netherlands, much to his surprise because for paternalistic reasons he was not told about his inevitable death. He could not return to his homeland or have his family at his 
deathbed. His fate made me very angry. I decided to study medical ethics. There was more than M: butchered abortions, the debate on euthanasia (still illegal in Holland at the time), research subjects being 'involved' without having a clue, prejudices about suitable parents, and many more cases that made me angry. Concrete change was needed. Although sadder and wiser now, I still find outrage a useful emotion.

Outrage inducing behaviours and cases:

- Arrogance and superiority of professionals on pedestals (including bioethicists)

- Carelessness and rudeness; lack of respect in general

- The short term (and short sighted) agenda of politicians

- The absolute certainties of fundamentalists (not, of course, my own fundamentalist anti-fundamentalism)

- Infringements of human rights and injustice in general and in detail

- Political issues, for example, considering the impeachment of President Obama for Obamacare

- Patients like Tony Nicklinson, Chantal Sébire, and a Swedish patient who suffered from amyotrophic lateral sclerosis, tried to commit suicide and failed and then was tied to his bed until he lost control of his arms because of the disease.

I therefore recommend that one should be personally involved in the issues one thinks and writes about and try to bridge the gap of 'moral distance'. This may seem obvious and even trivial, but it is not.

The next question is: how? What can a bioethicist offer? Is there a difference between bioethicists and others who aim to criticise and change practices?

\section{GOOD PHILOSOPHY AND GOOD FOR PHILOSOPHY?}

Reading Judith Jarvis Thomson's article on abortion and Jonathan Glover's book on end of life issues-exciting, of high quality and accessible-convinced me that it was possible to contribute to societal debates and to philosophy as well. ${ }^{2} 3$ Conceptual clarity, careful analysis, challenging presuppositions and daring arguments work both ways. Of course it can be difficult to find the balance between philosophical argument and practical applicability, but knowledge of the methods and theories of ethics that were developed during the long history of ethics as an academic discipline, is the expertise that distinguishes the bioethicist.

All bioethicists are equal of course, but some are more talented, original and acclaimed than others. We cannot all be Peter Singer, Martha Nussbaum, Thomas Pogge, John Harris, Govert den Hartogh, Alistair Campbell, Tom Beauchamp, Søren Holm, Maria Vanderwelde, Göran Hermerén, Raanan Gillon, Sven Kremer or Julian Savulescu. Note that mentioning them here does not mean they consider themselves as bioethicists. Note that by forgetting some people (yes, sorry, you!) or purposely not putting them on this list (no, of course not you!), I endanger my future career. Not too dangerous a predicament at my age but if you are young: proceed with care. The people on the list obviously are not to be blamed for being on it; the very debate about such lists is quite unpleasant although apparently inevitable in academic circles. Consider this an open list: please add your own examples and heroes.

A problem I have experienced regularly is that bioethicists encounter some disdain from 'real' philosophers who consider the endeavours of applied ethicists somewhat pathetic, superficial or ridiculous. Although that used to impress, even discourage, me when I was young, I now wonder: why? Is the Ivory Tower a better place? Should 'real' philosophers not write about such 'mundane' issues? Who is our audience anyway?
Recently I learned from a publisher that an article that I had written ( 2 months' work) had been downloaded 200 times. ${ }^{4}$ In my optimism I presumed that these people actually read it and each passed it on to one colleague, friend or spouse. Was 400 readers worth it, or should I have written five contributions for the popular press? (It would alleviate my doubts regarding the usefulness of my work if through mentioning it here, more people would read it.) Bioethics has many and very different audiences, varying from colleagues and professionals to lay audiences, which is good, but servicing (and pleasing) all is quite difficult (if not impossible).

\section{GOOD FOR INTERDISCIPLINARITY? BUT IS INTERDISCIPLINARITY GOOD?}

Bioethics has become an interdisciplinary field. Other disciplines participate. This is good. Splendid isolation of a philosophical kind is not an option anymore (for bioethicists, that is). But good to a certain extent. Some representatives of some disciplines (yes, the vagueness is on purpose) who enthusiastically jumped on the bandwagon tend to take over and think too easily: if medicine saved the life of ethics, it may save ours as well. I understand: jobs are scarce, sociologists and anthropologists may feel the same outrage and also want to contribute to change, but their knowledge does not replace ethical knowledge and skills. All can contribute provided they respect their own and others' expertise. (Note that although bioethics is in the Scrabble dictionary, bioethicist is not. Is this an ominous sign related to the problem of who can call himself a bioethicist?)

The drawbacks of interdisciplinary work are:

- The empirical seduction or trap. Some hold that philosophy is not a 'science' and does not have a 'scientific' method; it is speculative reasoning, rationalising gut feelings (be it with some ingenuity), or inventing cumbersome distinctions. As Plato, Kant and the like would never have managed to publish in The New England Journal of Medicine, philosophical argument can be ignored. If thinking is your 'business' and you do not do empirical research, then your activity has nothing to do with science. Such critics are not convinced by pointing out that philosophy has a long tradition in human history and that philosophical analysis is and always has been important. Of course interdisciplinary research and its empirical parts are important, but they cannot replace ethical analysis.

- The risk of dilution of ethical theory and arguments. I have sometimes been disappointed when seeing how little ethical argument was left after having produced an interdisciplinary article. Not to mention the nasty debates on authorship that turn people I previously thought of carrying the halo of scientific integrity with pride, into self-promoting piggybacking narcissists. (Young bioethicists: Welcome to the lion's den! Practical tip: do occasionally publish as sole author.)

- Paragraph ethics. Sometimes bioethics research is funded through participating in mega-medical-research projects. This can be exciting. But the emphasis on the term ethics in proposals can be disproportionate to the funds available for ethical research. Ethics can become sheer ornament, a lullaby for the policymakers ('Sleep well, dear minister, the bioethicists keep watch'). One is not always supposed to provide profound conceptual clarity or to demonstrate critical skills. Given the scarcity of funding many agree to be the ethics-appendix-researcher. I occasionally wonder whether there are too many bioethicists around? (Probably as sensitive as discussing general overpopulation.) We may be forced to reduce our art into tricks, sacrifice depth to palatability and 
facilitating the smooth digestion of ethical argument, master the higher arts of recycling ideas and hanging in distinguishiological trapezes, and reach consensus through confusion, not because it contributes to solving moral quandaries but in our struggle for professional survival.

- Closely related is the danger of becoming followers of fashion. For some reason, as enigmatic as getting women to wear block heels, some ethical 'schools' or buzzwords become fashionable at a particular time. When the right persons say that something matters, others think that therefore it matters. The Emperor's New Words indeed. Emphasising the 'right' methods and buzzwords and inflating one's capacities to sheer mythological proportions, may significantly increase one's chances of finding research money and general popularity (particularly with the media). It does, alas, not necessarily increase the quality of the ensuing ethical work. The buzzwords now are: nudging, public science, ethical framework, and anything with 'participatory' in it. Such notions can become straitjackets and lead one to sacrifice fascination to fashion and intellectual intrigue to routine.

Make a list of themes that fascinate you, even if non-buzz. This is my list:

- The Anthology of Literature on Medical Ethics (the sequel to Peter and Renate Singer's The Moral of the Story). ${ }^{5}$ Advice: do not underestimate the importance of (real and fictional) stories: they are crucial in moral thinking.

- XXXXX: the theme cannot be divulged as the work will be written with a famous ethicist who risks being copied, so this will be a Complete Surprise. (That is: if it ever gets written.)

- A Small Philosophy of Independence. On Coping with Dependence in an Independent Way

- The End(s) of Tolerance and the Art of Mildfulness

- What Sort of People Should There Be? (I know, this has already been written. By Jonathan Glover)

- Fun in Ethics, with chapters on the funniest analogies, the craziest arguments, the most miraculous metaphysical metaphors (Do not despair. Fun is possible.)

- A Misogynist View on Ethical Dilemmas (Probably I should write the one on fun first as it is more fun, but then people might think this one would also be fun, which of course it will absolutely not be. It will be very cynical and sad.)

\section{AGAIN: GOOD FOR CONTRIBUTING TO RESOLVING REAL LIFE ISSUES?}

One should, as I argued before, actually be in awe of 'real life' issues. Except for those who find complete and admirable satisfaction in adding, for example, footnotes to Plato, or addling their brains coming up with bizarre fictional cases (not to be confused with interesting uses of analogy arguments and notwithstanding the enjoyment of flirting with the bizarre and admiring the art of creating problems rather than solving them), being a part of real life debates provides the (ultimate) justification of the bioethical endeavour. This, however, also has its dangers:

- One might get lost in balancing between a view from nowhere and one's personal view (the debate on impartiality, etc, in ethics is complicated). People often ask: 'Pray tell, what is The Ethical Opinion?' The answer: 'Sorry, there is no such thing', is not what they want to hear.

- I keep asking myself: would I practise what I preach? Would I be willing to be a healthcare worker in an Ebola region? Would I perform abortions if I run the risk of being jailed? And if not, isn't it hubris to write about it?
- One might be crushed between the Scylla and Charybdis of the demands of theory and the demands of practice and feel that neither gets what it deserves.

- One may function as the lubricant in the strategic copulation of other parties and be exploited as the VEP (Very Ethical Person): 'We have a VEP on board and therefore what we do is ethical'. Most experienced bioethicists have Vepped, they have sat on committees as the Token Ethicist, Walking Conscience or Trophy Philosopher. The danger is to confuse value and success, and compromise and ethical validity. As said before: as we are in a way all tinkers who need to sell their merchandise in a climate of merciless competition, we run the risk of proposing philosophical shortcuts, following academic hearsay and heresy, and sometimes (unfairly) criticising those with different approaches and viewpoints, although of course the debate profits from different views and approaches, as long as one is clear about the ethical perspective used to frame the problem. In a world with many others who want to be the O(only)VEP, one may be tempted to bend some rules. It is hard to be generous when your academic survival is at stake. One might also succumb to the temptation of considering oneself a guru, as one has become a guru in the eyes of others. Popularity and 'oracle-status' are easily confused with being right. Some 400 groupies do not a guru make. Also a warning: guru status is rarely permanent.

- Despite the increasing popularity of bioethics, one might feel one is rearranging the deckchairs on the Titanic. I often fall victim to a crushing despair about the injustices in the world and feel ashamed of participating in the luxury of debating the First World's ethical issues. Given the fact that the world is on fire and life still nasty, brutish and short in many places, what can we do? Ethics is needed. But it is not certain that the need for ethics corresponds with a need for ethicists. One might argue, however, that issues such as autonomy and consent, etc, are at the heart of existential ethical questions that feed other debates.

I confess that I have:

- Used the slippery slope argument for rhetoric reasons (more than once, probably more than twice)

- Often wondered what good medical ethics is without admitting that I didn't know for fear that they would chose the Knowitallverycertaincompletelysure bioethicist (a comforting hindsight thought is that my doubts might be regarded as evidence for good ethics)

- Pretended to offer the maieutic help of Socrates whereas I actually had a clear idea on what kind of baby should be delivered

- Been bored, even by good ethics, even by good ethicists, and disguised this.

\section{TO DOUBT OR NOT TO DOUBT}

Whereas some prefer to provide certainty, I certainly hold the view that creating doubt and provoking people to reflecting about their moral views, even those written in stone, is an important task of bioethics and the best way to further the debate and improve practices. So I will listen to stories, try to refuel my outrage, and fight (with arguments) intolerance and lack of respect. Sometimes I wonder why I did not choose a different career.

What kept me going were:

- Making a difference even if small and only for one person

- An unexpected (or expected) really difficult puzzle

- The opportunity to be really intrigued by stories 
- A medical student in tears after reading Sylvia Plath's The Bell Jar, saying that it had changed his view on suicide

- To host 650 bioethicists from all over the world in Rotterdam and witness their exciting debates, inhaling the experience and the knowledge

- To be a member of a Dutch Euthanasia Committee, grateful to live in a country that has legalised euthanasia and grateful to the physicians who help suffering patients

- To write an ethical soap serial, published in this journal

- Being very proud of the accomplishments of our $\mathrm{PhD}$ students

- The inspiring doctors who took ethics seriously and indeed contributed to medicine saving the life of ethics

- Reading a philosophical masterpiece (and understanding it).

Advice: when you feel that bioethical life is exhausting, read a masterpiece. There are many philosophical masterpieces I wished that I had written (but they were written by others and I couldn't anyway). ${ }^{6-13}$

\section{ENVY}

I will always envy those with a Strong Single Cause, a Strong Ethical View and an Infallible Method that have accompanied them during their whole career. Envy those with a favourite philosopher on whose work they base their views (I wish I were a Kantian, well sometimes, I'm sure life as a Kantian can be excruciatingly difficult; being a Utilitarian of course causes some suffering as well). I envy those in clinics with beepers (or a modernish version of such a contraption) who are called to the bedside for Immediate Emergency Problem Solving, preferably in the middle of the night. It beats wrestling with yourself, roaming in a labyrinth and struggling in a swamp of doubt. I envy those who are not liberals. It is hard to be a liberal (in the good sense of the word), liberal ideas on pluralism are often confused with libertarianism and other Very Bad Things. Extreme views of a clear kind often are more popular. But I ifthatsallthereis myself and keep on writing. On the whole medical ethics has been good for/to me.

Acknowledgements I thank Göran Hermerén, Frans Meulenberg and Siobhan O'Sullivan for commenting on earlier versions.

Competing interests None.

Provenance and peer review Commissioned; internally peer reviewed.

\section{REFERENCES}

1 de Beaufort I, Meulenberg F. Eyewitness in Erewhon Academic Hospital: wuthering ethics. J Med Ethics 2010;36(7):385-6.

2 Thomson J. A defense of abortion. Philos Public Aff 1971;1:47-62.

3 Glover J. Causing Death and Saving Lives. Harmondsworth: Pelican, 1977.

4 de Beaufort I. Please, sir, can I have some more? Food, lifestyle, diets: respect and moral responsibility. Best Pract Res Clin Gastroenterol 2014;28:235-45.

5 Singer $P$, Singer R. eds. The Moral of the Story. Oxford: Blackwell, 2009.

6 Beauchamp T, Childress J. The Principles of Biomedical Ethics. 7th edn. Oxford: Oxford UP, 2013. (It is not a simple mantra, it is really helpful for all students of medical ethics.)

7 Dawkins R. The God Delusion. New York: Black Swan, 2007. (I admit, completely out of my field of expertise.)

8 Glover J. Humanity. New Haven/London: Yale UP, 1999.

9 Harris J. On Cloning. London \& New York: Routledge, 2004.

10 Radcliffe Richards J. The Skeptical Feminist. Harmondsworth: Penguin, 1982. (Also out of my field of expertise, but a treasure).

11 Sandel MJ. Justice. Harmondsworth: Penguin, 2010. (I admit I disagree with most of it, but it is fascinating).

12 Scruton R. I Drink therefore / Am. London: Continuum, 2009.

13 Singer P. The Life You Can Save. New York: Random House, 2009. 